\title{
PENGARUH VARIABEL MAKROEKONOMI TERHADAP PERTUMBUHAN SUKUK KORPORASI DI INDONESIA
}

\author{
Kurniawan \\ Program Studi Akuntansi, Fakultas Ekonomi, Universitas Islam Batik Surakarta \\ kurkur575@gmail.com \\ Endang Masitoh \\ Program Studi Akuntansi, Fakultas Ekonomi, Universitas Islam Batik Surakarta \\ yunmasitob@yahoo.com \\ Rosa Nikmatul Fajri \\ Program Studi Akuntansi, Fakultas Ekonomi, Universitas Islam Batik Surakarta \\ rosanikmatulfajri@mail.ugm.ac.id
}

\begin{abstract}
The capital market always develops over time. In addition to conventional capital markets, the Islamic capital market is also experiencing growth. This can be seen with the issuance of sukuk. Sukuk is an investment instrument based on sharia agreements, a country's financial condition has an important role in sukuk growth. Regarding current sukuk continues to increase, even though growth is still dependent on small numbers, it is necessary to know what factors influence the growth of sukuk relations in Indonesia. The purpose of this study is to study and analyze macroeconomic factors on the growth of corporate sukuk in Indonesia. This type of research is quantitative research with secondary data obtained from the official website of the Financial Services Authority. There are 38 research samples in which the sample is the same as the participants. The research method uses multiple linear regression models. The results of the study describe macroeconomic variables such as exchange rates, exchange rates, the amount of money contributing to the growth of corporate sukuk in Indonesia.
\end{abstract}

Keywords : Sukuk, Macroeconomic

\begin{abstract}
Abstrak : Pasar modal selalu mengalami perkembangan seiring berjalannya waktu. Selain pasar modal konvensional, pasar modal syariah juga mengalami perkembangan. Hal ini dapat dilihat dengan terbitnya sukuk. Sukuk merupakan instrumen investasi yang berdasar akad syariah, kondisi perekonomian suatu negara memiliki peran penting dalam pertumbuhan sukuk. Pertumbuhan sukuk saat ini terus meningkat, meski begitu pertumbuhan masih berada di angka yang kecil, maka dari itu perlu mengetahui faktor apa saja yang mempengaruhi pertumbuhan sukuk korporasi di Indonesia. Tujuan dari penelitian ini adalah untuk mengetahui dan menganalisis faktor variabel makroekonomi terhadap pertumbuhan sukuk korporasi di Indonesia. Jenis penelitian ini adalah penelitian kuantitatif dengan data sekunder yang di peroleh dari situs resmi Otoritas Jasa Keuangan. Terdapat 38 sampel penelitian dimana sampel sama dengan populasi. Metode penelitian menggunakan model regresi linear berganda. Hasil penelitian menjelaskan bahwa variabel makroekonomi seperti inflasi, nilai tukar, jumlah uang beredar memiliki pengaruh terhadap pertumbuhan sukuk korporasi di Indonesia.
\end{abstract}

Kata kunci : Sukuk, Makroekonomi

\section{A. Pendahuluan}

Pasar modal memiliki peran besar bagi perekonomian suatu negara karena pasar modal menjalankan dua fungsi sekaligus, fungsi ekonomi dan keuangan. Dengan adanya pasar modal diharapkan aktivitas perekonomian dapat meningkat karena pasar modal merupakan alternatif pendanaan bagi perusahaan-perusahaan sehingga perusahaan dapat beroperasi dengan skala yang lebih besar dan pada gilirannya akan meningkatkan pendapatan perusahaan dan kemakmuran masyarakat luas . ${ }^{1}$

${ }^{1}$ Darmadji, T., \& Fakhruddin, H. M. (2001). Pasar Modal di Indonesia : Pendekatan Tanya Jawab. Jakarta: 
Sebagai negara dengan presentase penduduk muslim terbesar di dunia, pasar modal syariah mengalami pertumbuhan yang pesat di Indonesia sejak kemunculannya pada tahun 1997. Tidak sedikit investor yang ingin menanamkan modalnya secara syariah. Pasar modal syariah terus mengalami perkembangan sehingga muncul obligasi syariah (sukuk) pada awal September 2002. Sukuk terbagi menjadi dua yaitu sukuk korporasi dan sukuk negara. Perkembangan sukuk korporasi di Indonesia terus mengalami perkembangan tiap tahunnya seiring berkembangnya perekonomian Indonesia. ${ }^{2}$

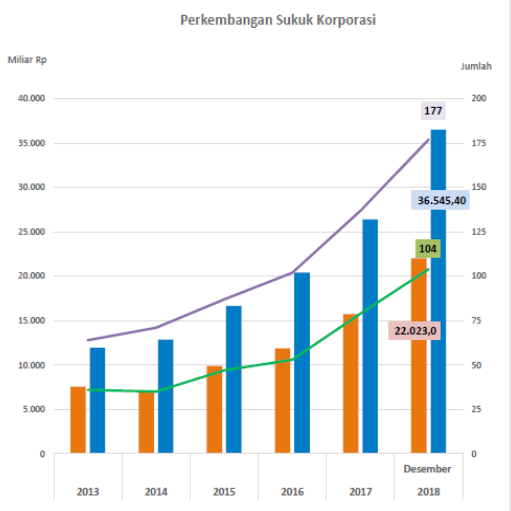

Sumber : (Otoritas Jasa Keuangan, 2019)

Gambar 1.Pertumbuhan Sukuk Korporasi

Melihat pekembangan sukuk korporasi di Indonesia tahun 2015-2018, pertumbuhan ekonomi mempengaruhi penerbitan sukuk korporasi. Peningkatan stabilitas ekonomi di tandai oleh menguatnya nilai tukar rupiah terhadap dollar, menurunya laju inflasi, suku bunga dan faktor makroekonomi lainya. ${ }^{3}$ Kondisi makroekonomi yang baik dapat mencerminkan iklim investasi pada suatu negara.

Dalam ilmu ekonomi, inflasi merupakan suatu proses meningkatnya harga-harga secara umum dan terus-menerus (continue) berkaitan dengan mekanisme pasar yang dapat disebabkan oleh berbagai faktor, antara lain, konsumsi masyarakat yang meningkat, berlebihnya likuiditas di pasar yang memicu konsumsi atau bahkan spekulasi, sampai termasuk juga akibat adanya ketidaklancaran distribusi barang. Malvin dalam penelitiannya yang berjudul pengaruh inflasi, jumlah uang beredar, dan imbal hasil Sertifikat Bank Indoesia Syariah (SBIS) terhadap total nilai emisi sukuk korporasi periode 2012-2015 menjelaskan bahwa inflasi memiliki pengaruh secara positif terhadap total nilai emisi sukuk korporasi Begitu juga dengan penelitian yang dilakukan oleh Malvin ditemukan hasil bahwa variabel jumlah uang beredar berpengaruh positif terhadap pertumbuhan sukuk korporasi. Hal ini sesuai dengan teori dimana dengan meningkatnya jumlah uang beredar maka berdampak pada kegiatan investasi yang semakin meluas. ${ }^{4}$ Selanjutnya, Hendriyani meneliti tentang analisis pengaruh inflasi, Harga Saham Gabungan (IHSG), dan jumlah uang beredar terhadap pertumbuhan sukuk korporasi pada pasar modal syariah Indonesia, hasil penelitian menjelaskan bahwa inflasi tidak mempunyai pengaruh terhadap nilai emisi sukuk. ${ }^{5}$

\footnotetext{
${ }^{2}$ Ardiansyah, I. H., \& Lubis, D. (2017). Pengaruh Variabel Makroekonomi Terhadap Pertumbuhan Sukuk Korporasi di Indonesia. Jurnal Al-Muzara'ah, 5, 1.

${ }^{3}$ Otoritas Jasa Keuangan. (2019). Retrieved Desember 27, 2019, from https://ojk.go.id/id/kanal/syariah/data-danstatistik/data-produk-obligasi-syariah/Default.aspx

${ }^{4}$ Malvin, R. (2017). Pengaruh Inflasi, Jumlah Uang Beredar, dan Imbal Hasil SBIS Terhadap Total Nilai Emisi Sukuk Korporasi. Jurnal Ekonomi dan Bisnis Universita Islam Negeri Syarif Hidayatullah, 74.

${ }^{5}$ Hendriyani, R. (2017). Analisis Pengaruh Inflasi, IHSG, dan Jumlah Uang Beredar Terhadap Pertumbuhan Sukuk Korporasi Pada Pasar Modal Syariah di Indonesia. Jurnal Manajemen Kenangan Syariah UIN Sunan Kalijaga Yogyakarta.
} 
Nilai tukar (kurs) adalah sebuah perjanjian yang dikenal sebagai nilai tukar mata uang terhadap pembayaran saat kini atau di kemudian hari, antara dua mata uang masing-masing negara atau wilayah. Widianti telah melakukan penelitian tentang pengaruh faktor maroekonomi terhadap pertumbuhan sukuk korporasi di indonesia periode 2011-2015, hasil penelitian tersebut menunjukkan bahwa nilai tukar berpengaruh secara negatif terhadap pertumbuhan sukuk korporasi. ${ }^{6}$ Penelitian lain juga dilakukan oleh Aprilia tentang analisis pengaruh variabel makroekonomi terhadap pertumbuhan sukuk korporasi indonesia tahun 2011-2018, hasil penelitian menujukkan bahwa nilai tukar IDR/USD tidak berpengaruh terhadap pertumbuhan sukukkorporasi Indonesia. ${ }^{7}$

Anindyarini dalam penelitiannya tentang Pengaruh inflasi, nilai ukar, dan sertifikat bank indonesia syariah terhadap pertumbuhan sukuk korporasi periode 2011-2016 juga menjelaskan bahwa nilai tukar memberikan pengaruh positif terhadap pertumbuhan sukukkorporasi periode 2011-2016. ${ }^{8}$ Dalam penelitian yang dilakukan oleh Hendriyani menjelaskan bahwa jumlah uang beredar mempunyai pengaruh positif terhadap nilai emisi sukuk. ${ }^{9}$

Dari hasil penelitian sebelumnya yang telah diuraikan, perlu adanya penelitian yang membahas pengaruh variabel ekonomi terhadap pertumbuhan sukuk korporasi di Indonesia. Tujuan dari penelitian ini untuk mengetahui dan menganalisis Pengaruh Variabel Makroekonomi inflasi, nilai tukar, dan jumlah uang beredar terhadap pertumbuhan sukuk korporasi di indonesia periode 2015-2018.

\section{Kajian pustaka}

\section{Teori Signal (Signalling theory)}

Signalling theory merupakan suatu informasi berupa sinyal yang diberikan untuk investor sehingga investor dapat mempertimbangkan kembali apakah akan menanamkan modalnya atau tidak". Sinyal tersebut tentang bagaimana cara perusahaan tersebut mendatangkan prospek sukuk yang diberikan apakah akan memberikan profit atau tidak. Semakin baik prospek perusahaan maka semakin menarik perhatian investor untuk menanamkan modalnya.$^{10}$

\section{Sukuk}

Sukuk dapat juga disebut sebagai obligasi syariah adalah surat berharga sebagai instrumen investasi yang diterbitkan berdasar suatu transaksi atau akad syariah yang melandasinya (underlying transaction), yang dapat berupa ijarah (sewa), mudharabah (bagihasil), musyarakah, atau yang lain. ${ }^{11}$

\section{Inflasi}

Inflasi adalah proses kenaikan harga harga umum secara terus menerus. Kejadian inflasi akan mengakibatkan menurunnya daya beli masyarakat. Hal ini terjadi dikarenakan dalam inflasi akan terjadi penurunan tingkat pendapatan inflasi dalam Inflation Targeting Framework. "Inflasi adalah kecenderungan harga harga untuk meningkat secara umum dan terus menerus". Pendapat lain

${ }^{6}$ Widianti, I. L. (2015). Pengaruh Faktor Makroekonomi Terhadap Pertumbuhan Sukuk Korporasi di Indonesia (Periode 2011-2015). Jurnal Syariah Dan Hukum UIN Syarf Hidayatulah.

Aprilia, A. (2019). Analisis Pengaruh Variabel Makro Ekonomi Terhadap Pertumbuhan Sukuk Korporasi Indonesia Tahun 2011-2018. Jurnal Ekonomi dan Bisnis Universitas Muhammadiyah Surakarta, 7.

\& Anindyarini, G. (2017). Pengaruh Inflasi, Nilai tukar, dan Sertifikat Bank Indonesia Syariah Terhadap Pertumbuhan Sukuk Korporasi Periode 2011-2016. Jurnal Ekonomi dan Bisnis Islam Intitut Agama IslamNegeri Tulungagung.

${ }^{9}$ Hendriyani, R. (2017). Analisis Pengaruh Inflasi, IHSG, dan Jumlah Uang Beredar Terhadap Pertumbuhan Sukuk Korporasi Pada Pasar Modal Syariah di Indonesia. Jurnal Manajemen Kenangan Syariah UIN Sunan Kalijaga Yogyakarta.

${ }_{10}$ Sugiyono. (2012). Metode Penelitian Bisnis (Pendekatan Kuatitatif, Kualitatif, dan R\&D). Bandung: Alfabeta.

${ }^{11}$ Al-Arif. (2012). Dasar-Dasar Pemasaran Bank Syariah. Bandung: Alfabeta.

${ }^{12}$ Wijayanta, B., \& Widyaningsih, A. (2007). Ekonomi Dan Akuntansi : Mengasah Kemampuan Ekonomi.

Jakarta: PT. Grafindo Media Pratama. 
menyebutkan inflasi merupakan risiko yang paling ditakuti oleh pemegang obligasi/sukukkarena inflasi akan menurunkan ukuran bunga dan keuntungan sebagaimana yang ditetapkan di awal perjanjian. Turunnya nilai mata uang akan melibatkan pembeli karena ia akan kehilangan uang sebanyak yang dibayarkan untuk membeli obligasi. ${ }^{13}$

\section{Jumlah uang beredar}

Uang beredar dapat didefinisikan dalam arti sempit (M1) dan dalam arti luas (M2). M1 meliputi uang kartal yang dipegang masyarakat dan uang giral (giro berdenominasi Rupiah), sedangkan M2 meliputi M1, uang kuasi (mencakup tabungan, simpanan berjangka dalam rupiah dan valas, serta giro dalam valuta asing), dan surat berharga yang diterbitkan oleh sistem moneter yang dimiliki sektor swasta domestik dengan sisa jangka waktu sampai dengan satu tahun. ${ }^{14}$

\section{Perumusan hipotesis}

Imani dalam penelitiannya mengemukakan hasil penelitian bahwa inflasi memiliki pengaruh terhadap pertumbuhan Sukuk. Semakin tinggi angka inflasi maka pertumbuhan sukuk juga akan meningkat. ${ }^{15}$ Sama dengan hasil penelitian Aprilia yang menunjukkan bahwa inflasi memiliki pengaruh terhadap pertumbuhan sukuk. ${ }^{16}$

$\mathrm{H}_{1} \quad$ : Inflasi berpengaruh terhadap pertumbuhan sukuk korporasi.

Anindyarini dalam penelitiannya menemukan hasil bahwa nilai tukar memiliki pengaruh terhadap pertumbuhan sukuk korporasi. Semakin tinggi nilai tukar Rupiah maka pertumbuhan sukuk juga akan meningkat. ${ }^{17}$ Sama seperti hasil penelitian menjelaskan bahwa nilai tukar berpengaruh terhadap pertumbuhan sukuk. ${ }^{18}$

$\mathrm{H}_{2} \quad$ : Nilai tukar berpengaruh terhadap pertumbuhan sukuk korporasi.

Hendriyani dalam penelitiannya menunjukkan hasil bahwa jumlah uang beredar berpengaruh terhadap pertumbuhan sukuk korporasi. Hal ini menujukkan bahwa meningkatnya jumlah uang beredar akan di ikuti dengan meningkatnya pertumbuhan sukuk. ${ }^{19}$ Begitu juga dengan hasil penelitian Malvin menjelaskan hasil bahwa variabel jumlah uang beredar berpengaruh terhadap pertumbuhan sukuk. ${ }^{20}$

$\mathrm{H}_{3} \quad$ : Jumlah uang beredar berpengaruh terhadap pertumbuhan sukuk korporasi.

\section{Metode penelitian}

Jenis penelitian yang digunakan adalah penelitian kuantitatif. Penelitian kuantitatif merupakan suatu proses menemukan pengetahuan yang menggunakan data berupa angka sebagai alat menganalisis keterangan mengenai apa yang ingin diketahui. Populasi dalam penelitian ini adalah pertumbuhan sukuk yang tercatat di Otoritas Jasa Keuangan (OJK) periode 2015-2018. sampel dalam penelitian ini adalah sama dengan populasi. Data penelitian

\footnotetext{
${ }^{13}$ Hulwati. (2006). Ekonomi Islam : Teori dan Praktiknya Dalam Perdagangan Obligasi Syariah di Pasar Modal Indonesia dan Malaysia. Jakarta: Ciputat Press.

${ }^{14}$ Bank Indonesia. (2019). Retrieved November 27, 2019, from Perkembangan Uang Beredar: https://www.bi.go. id/id/publikasi/perkembangan/Default.aspx

15 Imani, R. A. (2018). Pengaruh Hasil Inflasi dan Tingkat Suku Bunga Terhadap Harga Sukuk di Indonesia. Jurnal Ekonomi dan Bisnis Islam UIN Raden Fatah Palembang

16 Aprilia, A. (2019). Analisis Pengaruh Variabel Makro Ekonomi Terhadap Pertumbuhan Sukuk Korporasi Indonesia Tahun 2011-2018. Jurnal Ekonomi dan Bisnis Universitas Muhammadiyah Surakarta, 7.

17 Anindyarini, G. (2017). Pengaruh Inflasi, Nilai tukar, dan Sertifikat Bank Indonesia Syariah Terhadap Pertumbuhan Sukuk Korporasi Periode 2011-2016. Jurnal Ekonomi dan Bisnis Islam Intitut Agama IslamNegeri Tulungagung.

${ }^{18}$ Widianti, I. L. (2015). Pengaruh Faktor Makroekonomi Terhadap Pertumbuhan Sukuk Korporasi di Indonesia (Periode 2011-2015). Jurnal Syariah Dan Hukum UIN Syarfi Hidayatulah.

19 Hendriyani, R. (2017). Analisis Pengaruh Inflasi, IHSG, dan Jumlah Uang Beredar Terhadap Pertumbuhan Sukuk Korporasi Pada Pasar Modal Syariah di Indonesia. Jurnal Manajemen Kenangan Syariab UIN Sunan Kalijaga Yogyakarta.

${ }_{20}$ Malvin, R. (2017). Pengaruh Inflasi, Jumlah Uang Beredar, dan Imbal Hasil SBIS Terhadap Total Nilai Emisi Sukuk Korporasi. Jurnal Ekonomi dan Bisnis Universita Islam Negeri Syarif Hidayatullah, 74.
} 
merupakan time series. Data diambil secara bulanan yang diperoleh dari situs resmi Otoritas Jasa Keuangan. Teknik analisis data penelitian menggunakan model regresi linear berganda. Variabel yang digunakan dalam penelitian adalah inflasi, nilai tukar, jumlah uang beredar, dan pertumbuhan sukuk korporasi. Berikut pengukuran variabel dalam penelitian :

Sukuk $=$ Pertumbuhan sukuk korporasi yang tercatat di OJK periode $2015-2018$

$$
\text { Inflasi }=\frac{I H K n-I H K n_{-1}}{I H K n_{-1}} \times 100 \%
$$

Dimana :

IHKn : Indeks Harga Konsumen pada tahun $n$

$I H K n_{-1}:$ Indeks Harga Konsumen pada tahun sebelumnya

$M 2=M 1+$ Uang Kuasi + Surat Berharga selain saham

Dimana :

M2 : Uang beredar dalam arti luas

M1 :Uang beredar dalam arti sempit

Nilai Tukar $=$ Statistik nilai tukar dari di BI periode $2015-2018$

\section{B. Hasil dan Pembahasan}

Data sekunder dalam penelitian ini adalah pertumbuhan sukuk korporasi yang tercatat di Otoritas Jasa Keuangan (OJK). Pemilihan sampel dalam penelitian adalah sama dengan populasi.

Tabel 1. Pemilihan Sampel

\begin{tabular}{llc}
\hline No. & \multicolumn{1}{c}{ Keterangan } & Jumlah \\
\hline \multirow{2}{1}{} & Pertumbuhan sukuk korporasi yang tercatat di Otoritas Jasa Keuangan (OJK) periode & 48 \\
& $2015-2018$ & 48 \\
2 & Outlier data & $(10)$ \\
\hline 3 & Jumlah sampel penelitian & 38 \\
\hline & & Sumber : data sekunder diolah, 2019
\end{tabular}

Sumber : data sekunder diolah, 2019

\section{Analisis statistik deskriptif}

Tabel 2. Hasil Uji Statistik Deskriptif

\begin{tabular}{llrrrr}
\hline Variabel & N & \multicolumn{1}{c}{ Min } & \multicolumn{2}{c}{ Max } & \multicolumn{2}{c}{ Mean } & \multicolumn{2}{c}{ Std. Deviation } \\
\hline Sukuk & 38 & $12.956,40$ & $33.657,40$ & $21.661,26$ & $5.834,24$ \\
Inflasi & 38 & 2,79 & 7,26 & 4,10 & 1,35 \\
Nilai tukar & 38 & $12.937,00$ & $14.929,00$ & $13.557,74$ & 449,94 \\
M2 & 38 & $4.246 .361,19$ & $5.606 .779,89$ & $4.945 .634,15$ & $421.415,68$ \\
\hline
\end{tabular}

Sumber : data sekunder diolah, 2019

\section{Uji Normalitas}

Tabel 3. Hasil Uji Normalitas

\begin{tabular}{llll}
\hline Variabel & Signifikansi & Standart & Keterangan \\
\hline Sukuk,Inflasi & 0,200 & $>0,05$ & Normal \\
Nilai Tukar,M2 & & \\
\hline
\end{tabular}

Sumber : data sekunder diolah, 2019 


\section{Uji multikolinearitas}

Tabel 4. Hasil Uji Multikolinearitas

\begin{tabular}{llllll}
\hline Variabel & Tolerance & Standart & FIV & Standard & Keterangan \\
\hline Inflasi & 0,513 & $>0,1$ & 1,949 & $<10$ & Tidak terjadi Multikolinearitas \\
Nilai Tukar & 0,665 & $>0,1$ & 1,503 & $<10$ & Tidak terjadi Multikolinearitas \\
M2 & 0,383 & $>0,1$ & 2,608 & $<10$ & Tidak terjadi Multikolinearitas \\
\hline
\end{tabular}

Sumber : data sekunder diolah, 2019

\section{Uji autokorelasi}

Tabel 5. Hasil Uji Autokorelasi

\begin{tabular}{llll}
\hline Dl & DW & Du & Keterangan \\
\hline 1,3177 & $<1,443$ & $<1,6565$ & Tidak Ada Kepastian \\
\hline
\end{tabular}

Sumber : data sekunder diolah, 2019

Tabel 6. Hasil uji Run - Test

\begin{tabular}{lll}
\hline Signifikansi & Standart & Keterangan \\
\hline 0,139 & $>0,05$ & Tidak terjadi Autokorelasi \\
\hline
\end{tabular}

Sumber : data sekunder diolah, 2019

\section{Uji Heteroskedastisitas}

Tabel 7. Hasil Uji Heteroskedastisitas

\begin{tabular}{llll}
\hline Variabel & Signifikansi & Standard. & Keterangan \\
\hline Inflasi & 0,946 & $>0,05$ & Tidak terjadi Heteroskedastisitas \\
Nilai Tukar & 0,056 & $>0,05$ & Tidak terjadi Heteroskedastisitas \\
M2 & 0,674 & $>0,05$ & Tidak terjadi Heteroskedastisitas \\
\hline
\end{tabular}

Sumber : data sekunder diolah, 2019

\section{Model regresi linear berganda}

Tabel 8. Hasil Uji Regresi Linear Berganda

\begin{tabular}{lr}
\hline Variabel & $\boldsymbol{B}$ \\
\hline (Constant) & $-64.394,234$ \\
Inflasi & 355,557 \\
Nilai Tukar & 1,276 \\
M2 & 0,014 \\
\hline
\end{tabular}

Sumber : data sekunder diolah, 2019

\section{$Y=-64.394,234+355,557 \mathrm{X} 1+1,973 \mathrm{X} 2+0,014 \mathrm{X3}$}

Untuk menginterprestasikan hasil model regressi tersebut maka dapat dijelaskan bahwa Nilai konstanta (a) adalah $-64.394,234$, artinya jika variabel inflasi, nilai tukar, dan jumlah uang beredar nilainya adalah 0, maka pertumbuhan sukuk korporasi bernilai negatif yaitu -64.394,234.Nilai koefisien regresi variabel inflasi (X1) bernilai positif, yaitu 355,557. Artinya setiap inflasi meningkat sebesar 1 satuan, maka akan meningkatkan pertumbuhan sukuk korporasi sebesar 355,557 satuan. Nilai koefisien regresi variabel nilai tukar (X2) bernilai positif, yaitu 1,276. Artinya setiap nilai tukar meningkat sebesar 1 satuan, maka akan meningkatkan pertumbuhan sukuk korporasi sebesar 1,276 satuan.Nilai koefisien regresi variabel jumlah uang beredar (X3) bernilai positif, yaitu 0,014. Artinya setiap nilai tukar meningkat sebesar 1 satuan, maka akan meningkatkan pertumbuhan sukuk korporasi sebesar 0,014 satuan. 


\section{Uji kelayakan model (Uji F)}

Tabel 9.Hasil Uji Kelayakan Model (Uji F)

\begin{tabular}{lllll}
\hline F Hitung & F Tabel & Signifikansi & Standart & Keterangan \\
\hline 458,090 & $>2,883$ & 0,000 & $<0,05$ & Model Layak \\
\hline
\end{tabular}

Sumber : data sekunder diolah, 2019

\section{Uji hipotesis (Uji t)}

Tabel 10. Hasil Uji Hipotesis (Uji t)

\begin{tabular}{lrrrrc}
\hline Variabel & t Hitung & t Tabel & Signifikansi & Standart & Keterangan \\
\hline Inflasi & 2,207 & $>2,032$ & 0,034 & $<0,05$ & Diterima \\
Nilai tukar & 3,011 & $>2,032$ & 0,005 & $<0,05$ & Diterima \\
M2 & 22,844 & $>2,032$ & 0,000 & $<0,05$ & Diterima \\
\hline
\end{tabular}

Sumber : data sekunder diolah, 2019

Berdasarkan Hasil uji t pada variabel inflasi (X1) diperoleh nilai t hitung lebih besar dari t tabel, yaitu 2,207 >2,032, dan nilai signifikansi lebih kecil dari nilai standar, yaitu 0,034<0,05, Maka H1 diterima. Dapat disimpulkan bahwa inflasi berpengaruh terhadap pertumbuhan sukuk korporasi yang tercatat di OJK periode 2015-2018.

Berdasarkan Hasil uji t pada variabel nilai tukar (X2) diperoleh nilai t hitung lebih besar dari t tabel, yaitu 3,011 >2,032, dan nilai signifikansi lebih kecil dari nilai standar, yaitu 0,005 $<0,05$, Maka H2 diterima. Dapat disimpulkan bahwa nilai tukar berpengaruh terhadap pertumbuhan sukuk korporasi yang tercatat di OJK periode 2015-2018.

Berdasarkan Hasil uji t pada variabel jumlah uang beredar (X3) diperoleh nilai t hitung lebih besar dari t tabel, yaitu 22,844 >2,032, dan nilai signifikansi lebih kecil dari nilai standar, yaitu 0,000 $<0,05$, Maka H3 diterima. Dapat disimpulkan bahwa nilai tukar berpengaruh terhadap pertumbuhan sukuk korporasi yang tercatat di OJK periode 2015-2018.

\section{Koefisien determinasi}

Tabel 11. Hasil Uji Koefisien Determinasi

\begin{tabular}{lll}
\hline Model & Adjusted R Square & Std. Error of the Estimate \\
\hline 1 & 0,974 & 945,67496 \\
\hline
\end{tabular}

Sumber : data sekunder diolah, 2019

Berdasarkan hasil uji koefisien determinasi diperoleh nilai adjusted $R$ Squaresebesar 0,974. Hal ini menunjukkan bahwa variansi pada variabel pertumbuhan sukuk korporasi yang tercatat di Otoritas Jasa Keuangan (OJK) periode 2015-2018 sebesar 97,4\% dapat dijelaskan oleh variabel inflasi, nilai tukar, dan jumlah uang beredar, Sedangkan 2,6\% sisanya dijelaskan oleh faktor lain diluar variabel yang diteliti.

\section{Pembahasan}

Hasil hipotesis 1 menunjukan bahwa inflasi berpengaruh terhadap pertumbuhan sukuk korporasi yang tercatat di Otoritas Jasa Keuangan (OJK) periode 2015-2018. Periode tersebut tingkat inflasi dapat dikatakan stabil dan terkendali dengan nilai rata-rata pertumbuhan inflasi 4-5\%. Dampak inflasi adalah meningkatnya harga barang atau meleahnya niai mata uang rupiah, kebijakan yang tepat dalam menghadapi inflasi tersebut adalah dengan menanamkan modalnya atau berinvestasi, salah satunya investasi dalam bentuk sukuk karena memiliki instrumen pendapatan yang tetap. Meningkatnya inflasi tentu akan diikuti dengan meningkatnya suku bunga bank, maka emiten juga harus meningkatkan bunga yang harus dibayarkan kepada investor obligasi konvensional. Hal ini menjadikan emiten untuk menerbitkan sukuk sebagai alternatif dalam hal memperoleh dana perusahaan, sehingga pertumbuhan sukuk juga akan meningkat. Penelitian ini sejalan dengan 
penelitian hasill penelitian Ardiansyah \& Lubis dimana inflasi berpengaruh terhadap pertumbuhan sukuk korporasi di Indonesia. ${ }^{21}$ Penelitian ini juga sejalan dengan hasil penelitian Widianti yang menyatakan inflasi memiliki pengaruh terhadap pertumbuhan sukuk korporasi. ${ }^{22}$

Hasil hipotesis 2 menunjukkan bahwa nilai tukar berpengaruh positif terhadap pertumbuhan sukukkorporasi yang tercatat di Otoritas Jasa Keuangan periode 2015-2018. Hal ini dikarenakan menguatnya dollar terhadap menyebabkan nilai tukar rupiah menurun hingga level terendah, sehingga mengakibatkan Bank Indonesia meningkatkan suku bunga acuan. Hal ini yang mendorong emiten untuk menerbitkan sukuksebagai alternatif dalam memperoleh dana usaha. Selain itu industri keuangan syariah juga terus mengalami perkembangan sehingga permintaan dari industri keuangan syariah juga meningkat. Hal ini mendorong penerbitan sukukmeningkat dengan memanfaatkan permintaan industri keuangan syariah tersebut. Maka pertumbuhan sukukterus mengalami tren naik meski nilai rupiah mengalami pelemahan. Penelitian ini sejalan dengan hasil penelitian Anindyarini, 2017 dimana nilai tukar berpengaruh terhadap pertumbuhan sukukkorporasi di Indonesia. ${ }^{23}$

Hasil hipotesis 3 menunjukkan bahwa jumlah uang beredar (M2) berpengaruh terhadap pertumbuhan sukukkorporasi yang tercatat di Otoritas Jasa Keuangan periode 2015-2018. Hal ini karena ketika terjadi peningkatan pada jumlah uang beredar di masyarakat maka emiten akan menerbitkan sukuk sebagai instrumen yang dapat digunakan pada operasi pasar terbuka. Tujuan emiten menerbitkan sukuk adalah memperoleh dana dari masyarakat untuk melakukan perluasan saha, begitu juga dengan masyarakat akan lebih memilih menginvestasikan uangnya dalam bentuk sukuk daripada menyimpannya, karena dapat dipastikan mengalami penurunan nilai di masa mendadatang akibat peredaran uang yang tinggi. Hal ini sesuai teori dimana semakin banyak uang beredar maka akan meningkatkan kegiatan investasi yang semakin meluas. Penelitian ini sejalan dengan hasil penelitian yang dilakukan Hendriyani, dimana jumlah uang beredar memiliki pengaruh terhadap pertumbuhan sukukkorporasi di Indonesia. ${ }^{24}$. Penelitian ini juga didukung oleh Widianti yang menyatakan bahwa jumlah uang beredar berpengaruh terhadap pertumbuhan sukukkorporasi di Indonesia. ${ }^{25}$

\section{Kesimpulan}

Penelitian ini mencoba menganalisis pengaruh variabel makroekonomi terhadap pertumbuhan sukukkorporasi di Indonesia periode 2015-2018. Diperoleh 38 sampel penelitian. Berdasarkan hasil analisis data dengan menggunakan metode analisis regresi linear berganda dan pembahasan, maka dapat disimpulkan bahwa Inflasi memiliki pengaruh terhadap pertumbuhan sukukkorporasi di Indonesia. Meningkatnya inflasi akan diikuti dengan meningkatnya pertumbuhan sukukkorporasi di Indonesia. Nilai tukar memiliki pengaruh terhadap pertumbuhan sukukkorporasi di Indonesia. Hal ini menunjukkan bahwa meningkatnya nilai tukar akan diikuti dengan meningkatnya pertumbuhan sukukkorporasi di Indonesia. Jumlah uang beredar memiliki pengaruh terhadap pertumbuhan sukukkorporasi di Indonesia. Semakin meningkatnya jumlah uang beredar di masyarakat akan diikuti meningkatkan pertumbuhan sukukkorporasi di Indonesia.

\footnotetext{
${ }^{21}$ Ardiansyah, I. H., \& Lubis, D. (2017). Pengaruh Variabel Makro ekonomi Terhadap Pertumbuhan Sukuk Korporasi di Indonesia. Jurnal Al-Muzara'ah, $5,1$.

22 Widianti, I. L. (2015). Pengaruh Faktor Makroekonomi Terhadap Pertumbuhan Sukuk Korporasi di Indonesia (Periode 2011-2015). Jurnal Syariah Dan Hukum UIN Syarf Hidayatulah.

23 Anindyarini, G. (2017). Pengaruh Inflasi, Nilai tukar, dan Sertifikat Bank Indonesia Syariah Terhadap Pertumbuhan Sukuk Korporasi Periode 2011-2016

${ }^{24}$ Hendriyani, R. (2017). Analisis Pengaruh Inflasi, IHSG, dan Jumlah Uang Beredar Terhadap Pertumbuhan Sukuk Korporasi Pada Pasar Modal Syariah di Indonesia. Jurnal Manajemen Kenangan Syariah UIN Sunan Kalijaga Yogyakarta.

${ }^{25}$ Widianti, I. L. (2015). Pengaruh Faktor Makroekonomi Terhadap Pertumbuhan Sukuk Korporasi di Indonesia (Periode 2011-2015). Jurnal Syariah Dan Hukum UIN Syarf Hidayatulah.
} 


\section{Keterbatasan penelitian}

Variabel yang digunakan dalam penelitian hanya terdiri dari tiga variabel independen yaitu inflasi, nilai tukar, dan jumlah uang beredar. Masih banyak faktor lain yang mempengaruhi pertumbuhan sukuk korporasi baik makro ekonomi ataupun mikro ekonomi. Rentan waktu penelitian hanya 5 tahun, yaitu periode 2015-2018, sehingga hasil analis penelitian belum tentu sesuai dengan kondisi ekonomi pada periode sebelumnya ataupun setelahnya.

\section{Saran}

Meningkatkan peran pemerintah dalam memberikaan pemahaman sukuk kepada emiten dan mampu mendorong emiten untuk menerbitan sukuk sebagai upaya untuk mengendalikan perekonomian makro seperti inflasi dan uang beredar ke arah yang lebih baik. Masyarakat dapat menjadikan sukuk sebagai alternatif dalam berinvestasi karena sukuk bisamemberikan imbal hasil (return) yang lebih tinggi dan memiliki resiko relatif lebih rendah dengan prinsip-prinsip syariah yang melekat didalamnya.

\section{DAFTAR PUSTAKA}

Bank Indonesia. (2019). Retrieved November 27, 2019, from Perkembangan Uang Beredar: https:// www.bi.go.id/id/publikasi/perkembangan/Default.aspx

Otoritas Jasa Keuangan. (2019). Retrieved Desember 27, 2019, from https://ojk.go.id/id/kanal/ syariah/data-dan-statistik/data-produk-obligasi-syariah/Default.aspx

Al-Arif.(2012). Dasar-Dasar Pemasaran Bank Syariah. Bandung: Alfabeta.

Anindyarini, G. (2017). Pengaruh Inflasi, Nilai tukar, dan Sertifikat Bank Indonesia Syariah Terhadap Pertumbuhan Sukuk Korporasi Periode 2011-2016. Jurnal Ekonomi dan Bisnis Islam Intitut Agama IslamNegeri Tulungagung.

Aprilia, A. (2019). Analisis Pengaruh Variabel Makro Ekonomi Terhadap Pertumbuhan Sukuk Korporasi Indonesia Tahun 2011-2018. Jurnal Ekonomi dan Bisnis Universitas Muhammadiyah Surakarta, 7.

Ardiansyah, I. H., \& Lubis, D. (2017). Pengaruh Variabel Makro ekonomi Terhadap Pertumbuhan Sukuk Korporasi di Indonesia. Jurnal Al-Muzara'ah, 5, 1.

Darmadji, T., \& Fakhruddin, H. M. (2001). Pasar Modal di Indonesia : Pendekatan Tanya Jawab. Jakarta: Selemba Empat.

Hendriyani, R. (2017). Analisis Pengaruh Inflasi, IHSG, dan Jumlah Uang Beredar Terhadap Pertumbuhan Sukuk Korporasi Pada Pasar Modal Syariah di Indonesia. Jurnal Manajemen Keuangan Syariah UIN Sunan Kalijaga Yogyakarta.

Hulwati. (2006). Ekonomi Islam: Teori dan Praktiknya Dalam Perdagangan Obligasi Syariah di PasarModal Indonesiadan Malaysia. Jakarta: Ciputat Press.

Imani, R. A. (2018). Pengaruh Hasil Inflasi dan Tingkat Suku Bunga Terhadap Harga Sukuk di Indonesia. Jurnal Ekonomi dan Bisnis Islam UIN Raden Fatah Palembang.

Malvin, R. (2017). Pengaruh Inflasi, Jumlah Uang Beredar, dan Imbal Hasil SBIS Terhadap Total Nilai Emisi Sukuk Korporasi. Jurnal Ekonomi dan Bisnis Universita Islam Negeri Syarif Hidayatullah, 74.

Sugiyono. (2012). Metode Penelitian Bisnis (Pendekatan Kuatitatif, Kualitatif dan R\&D). Bandung: Alfabeta. 
Widianti, I. L. (2015). Pengaruh Faktor Makroekonomi Terhadap Pertumbuhan Sukuk Korporasi di Indonesia (Periode 2011-2015). Jurnal Syariah Dan Hukum UIN Syarf Hidayatulah.

Wijayanta, B., \& Widyaningsih, A. (2007). Ekonomi Dan Akuntansi: Mengasah Kemampuan Ekonomi. Jakarta: PT. Grafindo Media Pratama. 